\title{
JÓZEF MAROSZEK
}

Instytut Historii i Nauk Politycznych

Uniwersytet w Białymstoku

maroszek@vp.pl

\section{Jerzy Szumski, Starszy Notariusz Sądu Okrę- gowego w Grodnie [1581-1882] 1883-1915 [1920- -1930] Inwentarz zespotu akt, Białystok 2012, 122 strony}

Archiwum Państwowe w Białymstoku jest instytucją stale dostarczającą liczne publikacje drukiem (i w formacie PDF) informujące o zasobie posiadanych akt własnych i mikrofilmów zbiorów obcych. Ponadto wiele wydawnictw nosi charakter okazjonalno-rocznicowy wydarzeń historycznych, najczęściej dotyczących miasta Białegostoku, rzadziej województwa podlaskiego. Towarzyszy im szeroka akcja wystawiennicza plansz z ilustracjami przed siedzibą archiwum i w jego wnętrzu, wzbudzająca żywe zainteresowanie przechodniów i mieszkańców miasta.

Najcenniejsza - jak sądzę - dla badaczy-historyków regionu oraz zainteresowanych ustalaniem tytułów własności nieruchomości miejskich i wiejskich - jest publikacja Jerzego Szumskiego, Starszy Notariusz Sadu Okregowego w Grodnie [1581-1882] 1883-1915 [1920-1930] Inwentarz zespołu akt, Białystok 2012, 122 strony. Książka zaopatrzona jest w płytę CD. Posiada indeksy (opracowane po mistrzowsku!) - geograficzny (2132 hasła) i osobowy (32 871 haseł). Jest ona owocem wieloletniej pracy (1983-2007) tego archiwisty białostockiego. Jerzy Szumski wykazał w niej budzące najwyższe uznanie umiejętności: translatorskie, paleograficzne - w zakresie neografii rosyjskiej, chronologiczne, historii każdej miejscowości, historii białostockich, bielskich i sokólskich rodzin, ziemian (również Rosjan masowo posiadających tu majątki ziemskie i folwarki), historii ustroju rolnego - procesów parcelacji, wreszcie w zakresie uporządkowania na nowo zespołu archiwalnego. Jego praca jest efektem wieloletnich studiów nad ustrojem rolnym Królestwa Polskiego i Imperium Rosyjskiego w drugiej połowie XIX i pierwszej połowie XX w., ale też, a może przede wszystkim, mozolnej pracy archiwalnej. Taka ocena wybitnej wartości i poziomu publikacji jest możliwa przez piszącego te słowa, bo sam wiele lat spędzał na lekturze akt Starszego Notariusza Grodzieńskiego. Od kilkudziesięciu lat Jerzy Szumski stale konsultował wszystkich korzysta- 
jących z białostockiego archiwum, osoby bez jakiegokolwiek przygotowania do kwerend i umiejętności paleograficznych i językowych, ale bardzo zainteresowanych efektami poszukiwań własnościowych. Obecnie jest już na emeryturze.

Nie sposób pominąć tu faktu, że Archiwum Państwowe w Białymstoku jest niezwykle ubogie w akta sprzed 1944 r. Właściwie poza aktami pruskiej Kamery Wojen i Domen (1795-1807) i aktami rolnymi (1919-1939), wszystkie inne są jedynie szczątkami zespołów akt dawnych urzędów działających na tym obszarze lub niedużymi kolekcjami dokumentów wtórnie skompletowanymi. Właśnie akta Starszego Notariusza Sądu Okręgowego w Grodnie z lat 1883-1915 (w archiwum są tylko akta z powiatów: Bielsk Podlaski, Białystok i Sokółka, pozostałe powiaty guberni grodzieńskiej posiadają analogiczne akta $\mathrm{z}$ tych samych lat przechowywane w Centralnym Archiwum Historycznym w Grodnie) zaliczyć wypada do najcenniejszych i najważniejszych zespołów archiwum białostockiego. Dla drugiej połowy XIX i początków XX w. nie ma równego sobie zespołu.

Zespół Starszego Notariusza Grodzieńskiego (przechowywany w Białymstoku) obejmuje 32 metry bieżące akt. W inwentarzu autor przedstawił kolejno: dzieje ustrojowe urzędu, dzieje zespołu, jego charakterystykę archiwalną, zawartość, analizę metod porządkowania i opracowania. W aneksie umieścił spis ważniejszych dokumentów. Wobec faktu, że w latach 1956-1958 Mieczysław Kantorski wykonywał już prace porządkowe, segregując i inwentaryzując akta Starszego Notariusza, nadał jednostkom sygnatury, które były cytowane $\mathrm{w}$ opracowaniach historycznych i w dokumentacjach sądowych, dlatego Jerzy Szumski zamieścił konkordancje sygnatur dawnych (Kantorskiego) z nowymi. Najważniejszą część stanowi inwentarz 356 jednostek archiwalnych, podzielonych na sześć serii: Miasto Białystok (1-129), Powiat białostocki (130-189), Miasto Bielsk (190-201), Powiat bielski (202-273), Miasto Sokółka (274-285), Powiat sokólski (286-351). Archiwista podjął się tworzenia nowych jednostek, nawiązujących do ksiąg wieczystych, zakładanych w kancelarii starszego notariusza dla każdego miasta powiatowego i powiatu. Poszczególne sprawy ułożył w obrębie jednostek chronologicznie.

Wybór ważniejszych zregestowanych dokumentów został przeprowadzony z ogromnym znawstwem terenu, najważniejszych spraw i problemów, umożliwia przegląd tematów, które zasługują na badania historyczne. Zyskujemy też pełny pogląd na zawarty w poszczególnych jednostkach materiał kartograficzny - plany i wyrysy z nich - służące notariuszom w latach 1883-1915. 
Wydawnictwo dorobku Jerzego Szumskiego w zakresie zespołu Starszego Notariusza Grodzieńskiego jest najpewniej najcenniejszą pracą z zakresu historii regionalnej Podlasia w 2012 r. Wspomnieć wypada, że już wcześniej autor opublikował inne ważne dla źródłoznawstwa podlaskiego: Mikrofilmy akt metrykalnych parafii rzymskokatolickich archidiakonatu biatostockiego z lat 1808-1864. Informator, Białystok 2001, s. 218; Ogólny Spis ptatników państwowego podatku mieszkaniowego I Rejonu Podatkowego Miasta Białegostoku za 1915 r. Płatnicy podatku mieszkaniowego w Białymstoku 1914-1915. Indeks osobowy (wspólnie z Tomaszem Fiedorowiczem), Białystok 2010, s. 275.

Jerzy Szumski jest historykiem, który często, oparte na badaniach źródłowych, artykuły, referaty i komunikaty zamieszczał w "Archeionie”, „Kwartalniku Naukowym Białostocczyzna”, „Rubieżach”, "Studiach Podlaskich”, "Studiach Łomżyńskich", rocznikach regionalnych i tomach „Studiów i Materiałów", wydawnictwach pokonferencyjnych, prasie codziennej itd. (Zasługuje na uwagę jego monografia: Uwłaszczenie chłopów w pótnocno-wschodniej części Królestwa Polskiego 1846-1871, Białystok 2002, s. 293, opublikowana właśnie przez Archiwum Państwowe w Białymstoku). Postulować należy, aby białostockie archiwum zadbało również o przygotowanie tomu z przedrukiem prac rozproszonych, a ogromnie istotnych dla dziejów regionu, jednego z najlepszych archiwistów podlaskich. 